\title{
Bilateral mandibular dentigerous cyst in non-syndromic patient: technical strategy and literature review
}

\author{
Cisto dentígero mandibular bilateral em pacientes não sindrômicos: estratégia técnica e revisão da literatura \\ Quiste dentigero mandibular bilateral en paciente no sindrómico: estrategia técnica y revisión de la literatura \\ Henrique HADAD ${ }^{1}$ \\ Ana Flávia Piquera SANTOS ${ }^{1}$ \\ Luara Teixeira COLOMBO \\ Rodrigo Capalbo da SILVA ${ }^{1}$ \\ Pier Paolo POLI ${ }^{2}$ \\ Idelmo Rangel GARCIA JÚNIOR ${ }^{3}$ \\ Francisley Ávila de SOUZA $\mathbf{S}^{3}$ \\ ${ }^{1}$ DDS, Department of Diagnosis and Surgery, São Paulo State University (UNESP), School of Dentistry, 16015-050, Araçatuba, Brazil \\ ${ }^{2}$ MSc, Department of Biomedical, Surgical, and Dental Sciences of the University of Milan, 20122, Milano MI, Italy
}

DDS, MSc, PhD, Department of Diagnosis and Surgery, São Paulo State University (UNESP), School of Dentistry, 16015-050, Araçatuba, Brazil

\begin{abstract}
Unilateral dentigerous cyst is a common entity in the oral cavity. Conversely, bilateral dentigerous cysts are rare, especially in nonsyndromic patients. The purpose of the present article was to report a case of a bilateral dentigerous cyst in a non-syndromic patient and discuss about the treatment strategy. A literature review was perfomed and only eleven articles was report describing this condition. The orthopantomograph showed impacted wisdom teeth and a bilateral well-defined radiolucent unilocular image around the crown of the lower third molars. The diagnostic hypothesis was bilateral dentigerous cyst. The extraction of the impacted teeth was performed followed by excisional biopsy, which confirmed the diagnosis of dentigerous cyst. It might be concluded that radiographic examination is the first resource to intercept initial changes in the dental follicle through observation of the radiolucent halo. The histopathological examination of the surgical specimen becomes essential to reach a final diagnosis of the lesion.
\end{abstract}

Descriptors: Dentigerous Cyst; Molar, Third; Surgery, Oral.

\section{Resumo}

O cisto dentígero unilateral é uma entidade comum na cavidade oral. Por outro lado, cistos dentígeros bilaterais são raros, especialmente em pacientes não sindrômicos. O objetivo do presente artigo foi relatar um caso de cisto dentígero bilateral em um paciente não sindrômico e discutir sobre a estratégia de tratamento. Uma revisão da literatura foi realizada e apenas onze artigos foi um relatório descrevendo essa condição. O ortopantomógrafo mostrou dentes do siso impactados e uma imagem unilocular radiolúcida bilateral bem definida ao redor da coroa dos terceiros molares inferiores. A hipótese diagnóstica foi o cisto dentígero bilateral. A extração dos dentes retidos foi realizada seguida de biópsia excisional, que confirmou o diagnóstico de cisto dentígero. Pode-se concluir que o exame radiográfico é o primeiro recurso para interceptar alterações iniciais no folículo pericoronário através da observação do halo radiolucente. O exame histopatológico da peça cirúrgica torna-se essencial para o diagnóstico final da lesão.

Descritores: Cisto Dentígero; Dente Serotino; Cirurgia Bucal.

\section{Resumen}

El quiste dentígero unilateral es una entidad común en la cavidad oral. Por el contrario, los quistes dentígeros bilaterales son raros, especialmente en pacientes no sindrómicos. El propósito del presente artículo fue informar un caso de un quiste dentígero bilateral en un paciente no sindrómico y discutir sobre la estrategia de tratamiento. Se realizó una revisión de la literatura y solo once artículos fueron reportados describiendo esta condición. El ortopantomógrafo mostró muelas del juicio impactadas y una imagen unilocular radiolúcida bien definida bilateral alrededor de la corona de los terceros molares inferiores. La hipótesis diagnóstica fue quiste dentígero bilateral. La extracción de los dientes impactados se realizó seguida de una biopsia por escisión, que confirmó el diagnóstico de quiste dentígero. Se podría concluir que el examen radiográfico es el primer recurso para interceptar cambios iniciales en el folículo dental mediante la observación del halo radiotransparente. El examen histopatológico de la pieza quirúrgica se vuelve esencial para llegar a un diagnóstico final de la lesión.

Descriptores: Quiste Dentígero; Tercer Molar; Cirugía Bucal.

\section{INTRODUCTION}

The dentigerous cyst is considered the most common type of odontogenic developmental cysts, accounting for almost $20 \%$ of all cysts with epithelial lining affecting the gnathic bones. It originates from the separation of the follicle that surrounds an unerupted tooth, by means of an accumulation of liquid between the crown of the tooth and the reduced epithelium of the enamel ${ }^{1}$. Although it may be associated with any dental element, the teeth most commonly affected are third molars. Because the lesion is commonly asymptomatic, it is usually discovered in routine radiographs showing radiolucent lesion with well-defined sclerotic margins, associated with the crown of an impacted tooth in the cement-enamel junction ${ }^{2}$. A regular follicular space radiographically appears as a radiolucent area $<4 \mathrm{~mm}$. In case of a space $\geq 5 \mathrm{~mm}$, a dentigerous cyst might be considered ${ }^{3}$.
Due to its non-specific radiographic characteristics, the dentigerous cyst should be considered in differential diagnosis with other lesions such as unicystic ameloblastoma, odontogenic keratocyst, adenomatoid odontogenic tumor and odontoma $^{4-6}$. Histologically, the lesion is typically characterized by a capsule of thin loose connective tissue covered by non-keratinized epithelium, composed of two or three layers of lining cells, or cuboidal cells associated with a varying number of islands of odontogenic epithelium ${ }^{1,7}$. As with radiographic features, histological features are not sufficient to distinguish dentigerous cyst from other odontogenic cysts. It is therefore important to ensure that the lesion in question does not represent any other lesion with more specific characteristics ${ }^{1,7,8}$.

Treatments may vary between enucleation and marsupialization, depending on the 
characteristics of the patient and the lesion. In cases of smaller cysts associated with supernumerary or impacted teeth, or in cases where it is not possible to perform orthodontic traction of the element associated with the lesion, the enucleation treatment is indicated. In cases of pediatric patients, extensive lesions or when the tooth associated with the lesion has a potential for eruption, the technique of marsupialization can be used ${ }^{9,10}$.

Although they are considered common cysts, bilateral or multiple dentigerous cysts are rare and when they occur they are generally associated with certain syndromes, such as Maroteaux-Lamy syndrome (mucopolysaccharidosis type 4), nevoid basal cell carcinoma syndrome (Gorlin-Goltz Syndrome) and cleidocranial dysplasia ${ }^{11,12}$. A case has also been reported in the literature where the combined effect of cyclosporine with calcium blocker has led to the appearance of multiple dentigerous cysts 9 .

In view of the rarity associated with bilateral dentigerous cysts in non-syndromic patients, the objective of this study was 1) to report a clinical case of a patient diagnosed with bilateral dentigerous cyst, and 2) to briefly review to discuss literature findings with the present case, with emphasis on treatment and diagnosis.

\section{CLINICAL CASE}

A 19-year-old female patient affected by leukoderma, attended at the Oral and Maxillofacial Surgery Clinic of the Araçatuba Dental School Unesp after routine radiographic examination showing impacted third molars. In the available panoramic radiograph it was possible to observe the inclusion of the teeth $18,28,38$, and 48 . The teeth 38 and 48 fell into class II, position B, according to the Pell \& Gregory classification. ${ }^{13}$ All third molars were in mesio-angular position, according to the Winter classification ${ }^{14}$ with complete rhizogenesis. Around the dental crowns it was possible to observe a well delimited, clearly contoured, symmetrical radiolucent area with radiopaque halo of thin and unilocular thickness (Figure 1).

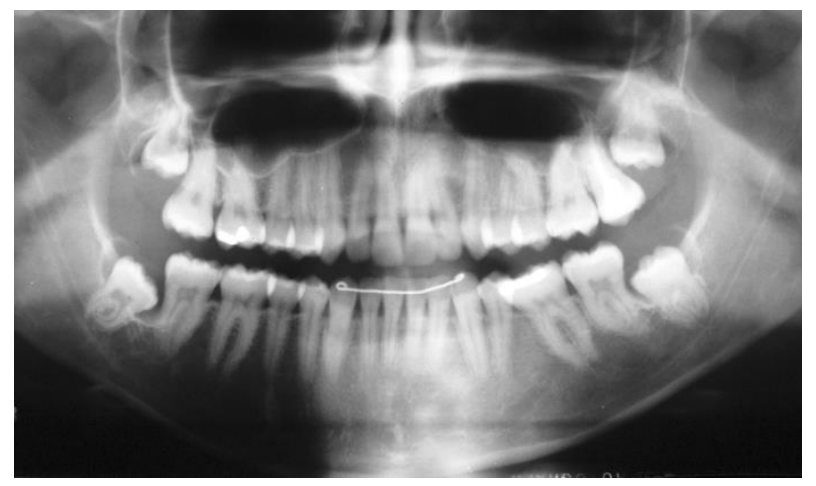

Figure 1: Initial panoramic radiograph showing radiolucent area around third molars.
Remarkably, the distance between the pericoronal hood and the dental crown of the lower wisdom teeth was roughly $5 \mathrm{~mm}$. The Donavan technique was also performed to locate the third molars. (Figure 2). The extraction of 18, 28, 38 and 48 was carried out, followed by excisional biopsy of the mandibular lesions. The histopathological examination resulted in pericoronary hood for the upper molars (Figure 3A and 3B). Histopathological examination of the parts collected in the lower molar region revealed a cavity covered by stratified squamous epithelium with few layers, and a fibrous capsule of connective tissue, with islands of odontogenic epithelium and inflammatory infiltrate, compatible with dentigerous cyst (Figure 3C and 3D).

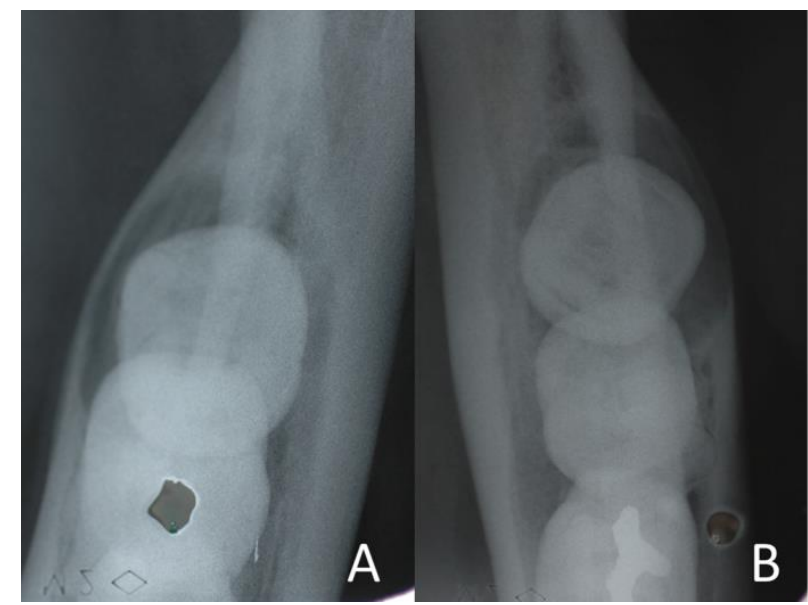

Figure 2: Donavan technique for third molars, A) right third molar and B) left third molar.

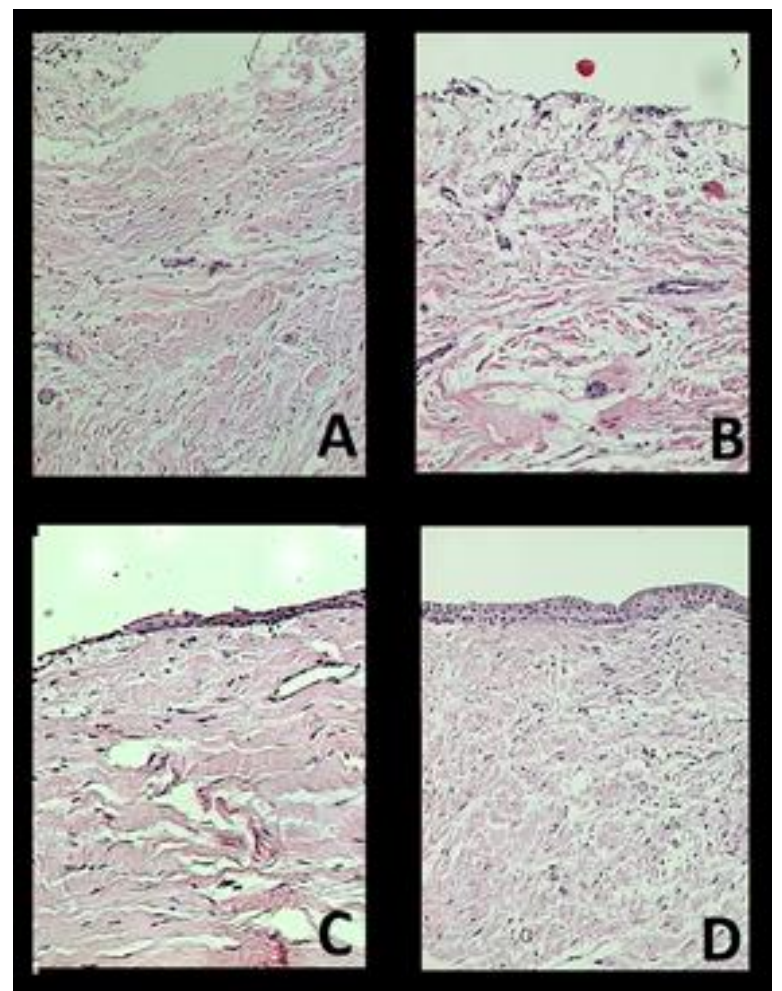

Figure 3: A) and B) histological section stained in HE (20x magnification), evidencing thin epithelium with predominantly loose connective capsule; C) and D) histological section stained in HE (20x magnification), evidencing a fibrous connective tissue with small islands of odontogenic epithelium rest, wrapped in a thin fibrous capsule. 
At the one-year follow-up recall, the postoperative panoramic radiograph (Figure 4) showed a physiological healing with favorable bone repair without other associated lesions or any other complications.

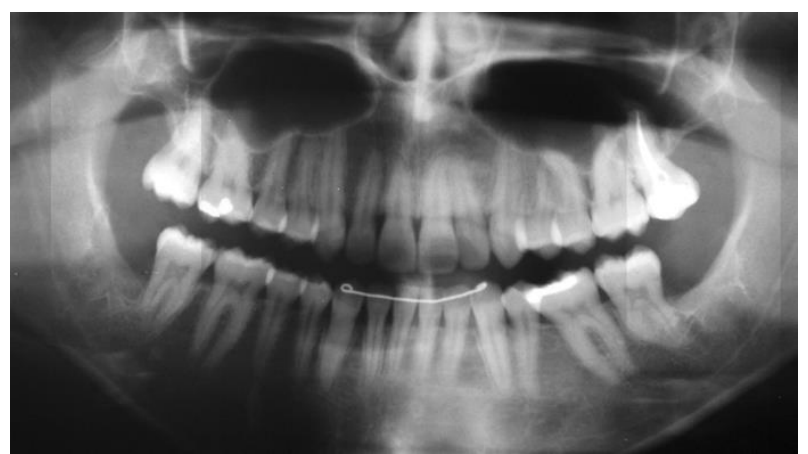

Figure 4: Panoramic radiography after 1 year of follow-up.

For a better discussion of this case, a literature review was conducted to identify published results and to compare with the present report. An english literature search was performed on PubMed database, using the key-words "bilateral dentigerous cyst" AND "non-syndromic". Only eleven articles between 1999-2018 describing this condition, emphasizing the rarity of the disease. The articles obtained from the search in the databases were organized as a table to facilitate the access to the information. (Table 1).

Table 1. Tabulation of the data obtained through the literature review on bilateral dentigerous cysts in non-syndromic patients.

\begin{tabular}{|c|c|c|c|c|c|}
\hline Author/year & Gender & Age & Location & Treatment & Diagnosis \\
\hline $\begin{array}{l}\text { Khandeparker } \\
\text { et al.17 } \\
2018\end{array}$ & Male & $10 y$ & $\begin{array}{l}\text { Maxilla } \\
\text { Canine }\end{array}$ & Enucleation & $\begin{array}{l}\text { Computed } \\
\text { Thomography } \\
\text { Histopathological } \\
\text { examination }\end{array}$ \\
\hline $\begin{array}{l}\text { Imada et al. }{ }^{18} \\
2014\end{array}$ & Female & $42 y$ & $\begin{array}{l}\text { Mandibular - } \\
\text { Third Molar }\end{array}$ & $\begin{array}{l}\text { Marsupialization } \\
\text { followed by } \\
\text { enucleation }\end{array}$ & $\begin{array}{l}\text { Computed } \\
\text { Thomography } \\
\text { Histopathological } \\
\text { examination }\end{array}$ \\
\hline $\begin{array}{l}\text { Sanjay et al. } 19 \\
2015\end{array}$ & Female & $24 y$ & $\begin{array}{l}\text { Mandibular - } \\
\text { Canine }\end{array}$ & Enucleation & $\begin{array}{l}\text { Panoramic } \\
\text { Radiograph } \\
\text { Histophatological } \\
\text { examination }\end{array}$ \\
\hline $\begin{array}{l}\text { Byatnal et al. }{ }^{20} \\
2020\end{array}$ & Male & $13 y$ & $\begin{array}{l}\text { Maxilla - } \\
\text { Supernumerary }\end{array}$ & $\begin{array}{l}\text { Enucleation } \\
\text { followed by } \\
\text { tooth extraction }\end{array}$ & $\begin{array}{l}\text { Computed } \\
\text { Thomography } \\
\text { Histopathological } \\
\text { examination }\end{array}$ \\
\hline $\begin{array}{l}\text { Ishihara et al. }{ }^{21} \\
2012\end{array}$ & Male & $13 y$ & $\begin{array}{l}\text { Mandibular - } \\
\text { Second } \\
\text { Pre-Molar }\end{array}$ & $\begin{array}{l}\text { Marsupialization } \\
\text { followed by } \\
\text { orthodontic } \\
\text { traction }\end{array}$ & $\begin{array}{l}\text { Computed } \\
\text { Thomography } \\
\text { Histopathological } \\
\text { examination }\end{array}$ \\
\hline $\begin{array}{l}\text { Shirazin et al. }{ }^{22} \\
2011\end{array}$ & Male & $10 y$ & $\begin{array}{l}\text { Mandibular - } \\
\text { Deciduous } \\
\text { Molars }\end{array}$ & Marsupialization & $\begin{array}{l}\text { Panoramic } \\
\text { Radiograph } \\
\text { Histopathological } \\
\text { examination }\end{array}$ \\
\hline $\begin{array}{l}\text { Prasad et al. } 23 \\
2010\end{array}$ & Female & $12 \mathrm{y}$ & $\begin{array}{l}\text { Maxilla } \\
\text { Canine }\end{array}$ & $\begin{array}{l}\text { Enucleation and } \\
\text { tooth extraction }\end{array}$ & $\begin{array}{l}\text { Computed } \\
\text { Thomography } \\
\text { Aspiration } \\
\text { Histopathological } \\
\text { examination }\end{array}$ \\
\hline $\begin{array}{l}\text { Saluja et al. } 24 \\
2010\end{array}$ & Female & $22 y$ & $\begin{array}{l}\text { All } \\
\text { quadrants }\end{array}$ & $\begin{array}{l}\text { Enucleation and } \\
\text { tooth extraction }\end{array}$ & $\begin{array}{l}\text { Panoramic } \\
\text { Radiograph } \\
\text { Histopathological } \\
\text { examination }\end{array}$ \\
\hline $\begin{array}{l}\text { Cury et al. }{ }^{25} \\
2007\end{array}$ & Male & $5 y$ & $\begin{array}{l}\text { Mandibular - } \\
\text { First Molar } \\
\text { Permanet }\end{array}$ & Enucleation & $\begin{array}{l}\text { Periapical } \\
\text { Radiograph } \\
\text { Panoramic } \\
\text { Radiograph } \\
\text { Histopathological } \\
\text { examination }\end{array}$ \\
\hline $\begin{array}{l}\text { Ustuner et al. }{ }^{26} \\
2003\end{array}$ & Male & $6 y$ & $\begin{array}{l}\text { Maxilla } \\
\text { Canine }\end{array}$ & Marsupialization & $\begin{array}{l}\text { Waters Radiograph } \\
\text { Computed } \\
\text { Thomography } \\
\text { Histopathological } \\
\text { examination }\end{array}$ \\
\hline $\begin{array}{l}\text { Ko et al. } .^{27} \\
1999\end{array}$ & Male & $42 y$ & $\begin{array}{l}\text { Mandibular } \\
\text { Third Molar }\end{array}$ & $\begin{array}{l}\text { Enucleation and } \\
\text { tooth extraction }\end{array}$ & $\begin{array}{l}\text { Panoramic } \\
\text { Radiograph } \\
\text { Histopathological } \\
\text { examination }\end{array}$ \\
\hline
\end{tabular}

\section{DISCUSSION}

The dentigerous cyst is the second most common odontogenic cyst in the oral cavity, with 1.44 cases reported for every 100 impacted teeth ${ }^{15,16}$, however, cases involving the diagnosis of bilateral cyst are rare, particularly if considering nonsyndromic patients ${ }^{9,11,12}$.

The literature shows a greater involvement of male gender $(63,6 \%)^{17,20-22,25-27}$ compared to female patients $(36,3 \%)^{18,19,23,24}$, with infantile and young adult patients being more affected $(81,81 \%)^{17,19,20-26}$ with respect to adult patients $(18,18 \%)^{18,27}$. The higher incidence in children and young patients seems to be related to the association with unerupted dental elements in the oral cavity.

Due to its characteristic slow and asymptomatic pattern of growth, this cyst is often discovered through radiographs in which the diagnosis is sought for impacted teeth ${ }^{2}$. However, radiographic findings alone are not sufficient to obtain a definitive diagnosis of dentigerous cyst. Other lesions such as keratocysts, unicystic ameloblatomas and many others may present radiographic features that are essentially identical to those of the dentigerous cyst ${ }^{1}$.

It is surgeon responsibility to observe by means of imaging examination if the dental follicle is larger when compared to a normal dental follicle, through computed tomography ${ }^{17,18,20,21,23,26}$, panoramic radiography ${ }^{19,22,24,25,27}$, periapical ${ }^{25}$ and Waters' projection ${ }^{27}$. In addition, during the surgical procedure of tooth extraction, it is mandatory to observe the thickness of the dental follicle and identify clinical signs suggestive of the presence of cysts.

Although the review of the articles presented herein showed that all authors performed the anatomopathological examination of pericoronal tissue after extraction, most of the surgeons do not submit the removed material for diagnosis. Therefore, the incidence of anomalies associated with impacted third molars might be underreported. ${ }^{18,27}$

Isolated cases of bilateral dentigerous cyst presented higher prevalence in the mandible $e^{18,19,21,22,25,27}$. In only one case the lesion affected both maxilla and mandible simultaneously ${ }^{24}$. Although only eleven cases have been found in this literature review, the number of cases involving mandibular third molars are less expressive $\mathrm{e}^{1,18,27}$.

Looking at the treatment options, the dentigerous cysts were basically approached by two techniques: enucleation ${ }^{17,19,20,23-25,27}$ and marsupialization $^{21,22,26}$, with only one case showing marsupialization followed by enucleation. Other approaches including tooth extraction ${ }^{20,23,24,27}$ related to injury were established in some cases and while dental traction was reported once ${ }^{21}$.

The choice of the technique to treat these lesions should be based on several aspects, such as the dimensions of the lesion itself, dental elements involved, proximity to important anatomical structures, vascular and nervous bundles ${ }^{28,29}$. Large 
lesions are usually approached by initial decompressive marsupialization, in order to decrease the bone defect. This technique is associated with the enucleation of the lesion to prevent possible relapses, even if they are rare.

Only four authors 18,21,23,25 reported the follow-up of the cases treated, with a period ranging from 6-24 months. Epidermoid carcinoma may arise from the lining of the remaining cyst, and it is likely that some intraosseous mucoepidermoid carcinomas develop from the mucosal cells present in the lining of the dentigerous cyst $^{1,30-32}$. Furthermore these lesions may undergo neoplastic transformation, stressing the importance of follow-up recalls of patients previously affected by dentigerous cysts ${ }^{31-33}$.

\section{CONCLUSION}

Radiographic examination is the first resource used to obtain an early provisional diagnosis of a possible change in the dental follicle through observation of the radiolucent halo. It is extremely important to send the surgical specimen for anatomic pathology examination. The histopathological report together with radiographs and complementary information allows obtaining the definitive diagnosis. For this reason, a careful anamnesis associated with clear radiographic examination is necessary so that both surgical procedure and diagnostic workup can be successful.

\section{REFERENCES}

1. Daley TD, Wysocki GP, Pringle GA. Relative incidence of odontogenic tumors and oral and jaw cysts in a Canadian population. Oral Surg Oral Med Oral Pathol. 1994;77(3):276-80.

2. Zhang LL, Yang R, Zhang L, Li W, MacDonaldJankowski D, Poh CF. Dentigerous cyst: a retrospective clinicopathological analysis of 2082 dentigerous cysts in British Columbia, Canada. Int J Oral Maxillofac Surg. 2010;39(9):878-82.

3. Farah CS, Savage NW. Pericoronal radiolucencies and the significance of early detection. Aust Dent J. 2002;47(3):262-265.

4. Ricucci D, Mannocci F, Ford TR. A study of periapical lesions correlating the presence of a radiopaque lamina with histological findings. Oral Surg Oral Med Oral Pathol Oral Radiol Endod. 2006;101(3):389-94.

5. Vencio EF, Mota A, de Melo Pinho C, Dias Filho AA. Odontogenic keratocyst in maxillary sinus with invasive behaviour. J Oral Pathol Med. 2006;35(4):249-51.

6. Al-Khateeb TH, Bataineh AB. Pathology associated with impacted mandibular third molars in a group of Jordanians. J Oral Maxillofac Surg. 2006;64(11):1598-602.

7. Motamedi MH, Talesh KT. Management of extensive dentigerous cysts. $\mathrm{Br}$ Dent $\mathrm{J}$. 2005;198(4):203-6.
8. Smith G. Two dentigerous cysts in the mandible of one patient. Case report. Aust Dent J. 1996;41(5):291-93.

9. Fujii R, Kawakami M, Hyomoto M, Ishida J, Kirita T. Panoramic findings for predicting eruption of mandibular premolars associated with dentigerous cyst after marsupialization. J Oral Maxillofac Surg. 2008;66(2):272-76.

10. Motamedi MH, Talesh KT. Management of extensive dentigerous cysts. $\mathrm{Br}$ Dent J. 2005;198(4):203-6.

11. Tamgadge A, Tamgadge S, Bhatt D, Bhalerao S, Pereira T, Padhye M. Bilateral dentigerous cyst in a non-syndromic patient: Report of an unusual case with review of the literature. J Oral Maxillofac Pathol. 2011;15(1):91-5.

12. Aher V, Chander PM, Chikkalingaiah RG, Ali FM. Dentigerous cysts in four quadrants: a rare and first reported case. J Surg Tech Case Rep. 2013;5(1):21-6.

13. Pell GJ, Gregory GT. Impacted mandibular third molars: Classification and modified technique for removel. Dent Dig 1933; 39:330-38.

14. Winter GB. Principles of exodontia as applied to the impacted third molar. St Louis: American Medical Books; 1926.

15. Daley TD, Wysocki GP, Pringle GA. Relative incidence of odontogenic tumors and oral and jaw cysts in a Canadian population. Oral Surg Oral Med Oral Pathol. 1994;77(3):276-80.

16. Shafer WG, Hine MK, Levy BM. A Textbook of Oral Pathology. 4th ed. Philadelphia: Saunders; 1983. 258-317

17. Khandeparker RV, Khandeparker PV, Virginkar A, et al. Bilateral Maxillary Dentigerous Cysts in a Nonsyndromic Child: A Rare Presentation and Review of the Literature. Case Rep Dent 2018; 2018:7583082.

18. Imada TSN, Tieghi Neto V, Bernini GF, Silva Santos PS, Rubira-Bullen IR, Bravo-Calderón D et al. Unusual bilateral dentigerous cysts in a nonsyndromic patient assessed by cone beam computed tomography. Contemp Clin Dent. 2014;5(2):240-42.

19. Sanjay CJ, David CM, Kaul R, Shilpa PS. Kissing dentigerous cysts involving mandibular canines: report of unusual case with review of literature. J Calif Dent Assoc. 2015;43(1):29-33.

20. Byatnal A, Byatnal A, Singh A, Narayanaswamy V, Radhakrishnan R. Bilateral impacted inverted mesiodens associated with dentigerous cyst. J Calif Dent Assoc. 2013;41(10):753-57.

21. Ishihara $\mathrm{Y}$, Kamioka $\mathrm{H}$, Takano-Yamamoto $\mathrm{T}$, Yamashiro T. Patient with nonsyndromic bilateral and multiple impacted teeth and dentigerous cysts. Am J Orthod Dentofacial Orthop. 2012;141(2):228-241. 
22. Shirazian S, Agha-Hosseini F. Non-syndromic bilateral dentigerous cysts associated with permanent second premolars. Clin Pract. 2011;1(3):e64.

23. Prasad LK, Chakravarthi PS, Sridhar M, Ramakumar Y, Kattimani V. Nonsyndromic Bilateral Maxillary and Unilateral Mandibular Multiple Dentigerous Cysts in a Young Girl: Report of a Rare Case. Int J Clin Pediatr Dent. 2010;3(3):219-23.

24. Saluja JS, Ramakrishnan MJ, Vinit GB, Jaiswara C. Multiple dentigerous cysts in a nonsyndromic minor patient: Report of an unusual case. Natl $\mathbf{J}$ Maxillofac Surg. 2010;1(2):168-72.

25. Cury SEV, Cury MDPN, Cury SEN, Pontes FSC, Pontes HAR, Rodini $\mathrm{C}$ et al. Bilateral dentigerous cyst in a nonsyndromic patient: case report and literature review. J Dent Child (Chic). 2009;76(1):92-6.

26. Ustuner E, Fitoz S, Atasoy C, Erden I, Akyar S. Bilateral maxillary dentigerous cysts: a case report. Oral Surg Oral Med Oral Pathol Oral Radiol Endod. 2003;95(5):632-35.

27. Ko KS, Dover DG, Jordan RC. Bilateral dentigerous cysts--report of an unusual case and review of the literature. J Can Dent Assoc. 1999;65(1):49-51.

28. Chew YS, Aghabeigi B. Spontaneous regression of bilateral dentigerous cysts: a case report. Dent Update. 2008;35(1):63-5.

29. Shah N, Thuau H, Beale I. Spontaneous regression of bilateral dentigerous cysts associated with impacted mandibular third molars. Br Dent J. 2002;192(2):75-6.

30. Aggarwal P, Saxena S. Aggressive growth and neoplastic potential of dentigerous cysts with particular reference to central mucoepidermoid carcinoma. Br J Oral Maxillofac Surg. 2011; 49(6):e36-9.

31.Zapała-Pośpiech A, Wyszyńska-Pawelec G, Adamek D, Tomaszewska R, Zaleska M, Zapała J. Malignant transformation in the course of a dentigerous cyst: a problem for a clinician and a pathologist. Considerations based on a case report. Pol J Pathol. 2013;64(1):64-8.

32. Spoorthi BR, Rao RS, Rajashekaraiah PB, Patil S, Venktesaiah SS, Purushothama P. Predominantly cystic central mucoepidermoid carcinoma developing from a previously diagnosed dentigerous cyst: case report and review of the literature. Clin Pract. 2013;3(2):e19.

33. Bereket C, Bekçioğlu B, Koyuncu M, Şener İ, Kandemir B, Türer A. Intraosseous carcinoma arising from an odontogenic cyst: a case report. Oral Surg Oral Med Oral Pathol Oral Radiol. 2013;116(6):e445-49.

\section{CONFLICTS OF INTERESTS}

The authors declare no conflicts of interests.

\section{CORRESPONDING AUTHOR}

\section{Ana Flávia Piquera Santos anaflaviaps_06@hotmail.com \\ Department of Surgery and Integrated Clinic, Araçatuba Dental School, São Paulo State University "Júlio de Mesquita Filho" - UNESP Rua José Bonifácio 1193, Vila Mendonça, 16015-050, Araçatuba, São Paulo, Brazil. \\ Phone: +55 18 3636-2898}

Received 04/07/2019

Accepted 20/04/2020 